Proceedings of the International Scientifical Conference. Volume II: Social and Special pedagogy; Health and Sport; Overviews.

\title{
PROMOTION OF ADULT EDUCATION IN THE INNOVATIVE BUSINESS
}

\section{Pieaugušo izglītības veicināšana inovatīvā uzṇēmējdarbībā}

\author{
Daina Silakalne - Arāja \\ University of Latvia, Latvia \\ E-mail: danha@inbox.lv
}

\author{
Raimonds Arājs \\ Rezekne Higher Education Institution, Latvia \\ E-mail: arajsraimonds@inbox.lv
}

\begin{abstract}
The notions of adult education and innovative entrepreneurship have been described and analysed in the article. According to the characterization of the essence of notions, conditions of innovative entrepreneurship have been analysed. The emphasis has been put on the main problem concerning sustainable community development related to the contributions made to human resources and adult education, enabling innovative entrepreneurship oriented on the human ability to create and use their knowledge in constantly changing environmental conditions, responsible for work organisation satisfying current people's social and economical needs, thought at the same time not endangering next generations. The following theories like the essence and process of adult education, innovations as a source of a rising viability and competitiveness and development trends of innovative activities in Latvia and the rest of the world are revealed in the article.
\end{abstract}

Keywords: adult education, innovative entrepreneurship, lifelong learning, further education, innovation, innovative activity, scientist, entrepreneur, innovative product, innovative enterprise, self-directed adult learning.

\section{Introduction}

Sustainable community development is one of the most important issues in the 21 st century. It is a balanced and integrated development of the community's welfare, environment and economy which satisfies the current people's social and economic demands and does not endanger opportunities of satisfying demands of the next generations. In the context of sustainable community development, the human resources and innovative entrepreneurship ensuring requirements of environmental observation are of a great importance. In nowadays the biggest threat is the crisis of human competence. Insufficient competence either of particular individuals or the whole community is one of the causes of different crises. Human learning according to the age is very topical. Innovation and innovative activities is the main human resource quality indicator that is the basis of the development of economical and social life in economically developed countries. Innovation includes all the activities happening within the society research work and product realization along with the management of business environment and creation of innovative support structures. Innovative entrepreneurship is oriented towards the human ability to create and use their knowledge in constantly changing environmental conditions. The global economy 
and society become increasingly dependent on the knowledge and the speed of its exchange, the rising efficiency of production and the eligibility of products to the market demands. It also depends on the harmonized interaction of all innovation system's elements: education - science - production - legislation - financing, as well as on many other environmental factors which can enhance competitiveness of enterprises and help them to be ready to face different challenges in the future.

\section{The Content of Adult Education}

Well known scientists like Darkenwald G.G. and Merriam S.B. (1982) consider adult education to be a process in which people, whose main social roles are characteristic to the adult status, take part in systematic and sustained learning activities for changing their knowledge, values, attitude or skills.

According to scientist Knowles M.S. (1988), Andragogy is a science and an art of helping adults to learn. He emphasizes the importance of practice and critical thinking that are also significant matters of innovative entrepreneurship.

Scientist Stasane J. (Stašāne J., 2007) developed the theory about adult education management at a lifelong learning process. Adult education can be described as an adult learning process and providing a lifelong support that is connected with such specific questions like voluntary nature of study, contributions in a personal growth and development as well as determined and deliberate structure of learning.

The Latvian Adult Education Association defines "adult education" in a following way: "Adult education is a part of educational system providing an opportunity of a lifelong learning for people according to their needs and abilities as well as trends of the nature and community development, regardless of their previous education level. Adult education comprises general, professional and public education. It enables the development of a free, creative and cultural personality and its successful integration in the society is based on a common understanding of values, acquirements of cultural heritage, transfer and cultivation of self-reliance, which helps to provide the necessary level of knowledge and skills that are required for a particular occupation as well as other people's needs and activities." (The Latvian Adult Education Association, 1997).

UNESCO educational policy (UNESCO, 2000) accentuates two main aspects: education available to all people; education as a lifelong and continued process. UNESCO education policy is oriented towards the society which is in a constant process of acquiring knowledge. Latvian Lifelong Learning Policy Guidelines for 2007-2013 state that adult education is formal, informal and daily learning providing personal development, social inclusion, civic participation and a lifelong competitiveness in the labour market. Lifelong education has become the main feature of the countries in which community development is based on invariable cultural values, exchange of information, communication and modern technologies.

According to the Law of Education issued by the Ministry of Education and Science of the Republic of Latvia, adult education is a varied educational process 
Proceedings of the International Scientifical Conference. Volume II: Social and Special pedagogy; Health and Sport; Overviews. of people that provides a lifelong personal development and competitiveness in the labour market by offering people formal and informal educational programmes.

Liegeniece D. (Lieǵeniece D., 2002) emphasizes that adult education is a part of the educational system, which provides an opportunity of a lifelong learning to people regardless of their previous education level. It is oriented towards selfimplementation of an individual and community development.

Adult education is affected by collaboration of the state, employer, employee and educational system. If this collaboration is successful and mutually supportive, we can forecast the possible innovations in the entrepreneurship.

The European Commission's "Memorandum on Lifelong Learning" (2002) presents an idea that Europe's main asset is the man; therefore, a plan of increasing investments in human resources appears. To the great extent innovative entrepreneurship depends on the quality of people's education. In the context of a lifelong education the following basic skills for all people are accentuated, which are also included in the conclusions of the Lisbon European Council: information and communications technology (ICT) skills; foreign languages; technological culture; entrepreneurship; social skills. Koke T. (Koķe T., 1999), a scientist, emphasizes the importance of following skills have already been started developed at school: an ability to create new knowledge and development of research skills. The necessity of research skills are practically used in every sphere of life, including entrepreneurship and can be explained by the need of analysing, evaluating, experimenting, planning, making decisions and conclusions, taking the risk and reducing it by the help of new knowledge. In nowadays the notion "research" does not refer solely in the academic sphere. Research in the innovative entrepreneurship is related to the necessity to develop the science from the theory to practice and vice versa. Therefore, research comprises not only creating new knowledge, but also cognition of the expediency acquired previously. According to the experience of the authors of the article, organized educational activities for adults and trainees, which are involved in the process for adult education, can be divided into the following groups:

- hardworking trainees - willing to acquire all the necessary knowledge and skills, as well as take part and co-operate in the process of education- both for theoretical and practical activities;

- impulsive trainees - the main quality of their nature is expressed in frequent mood changes followed by spontaneous and unpredictable actions;

- friendly trainees - the main idea is to maintain good and friendly relationships with their group mates and teaching staff;

- negatively minded trainees - never satisfied with anything as well as they are sceptically minded towards any requirements and the organization of education process;

- trainees loving to take risks - it is important to demonstrate themselves in risky situations; 
- unconfident trainees - cannot objectively evaluate their abilities, skills and knowledge.

When organizing the process of adult education it is essential to keep in mind all these character groups of trainees which are common for both sex - men and women. The dominating educational methods for organizing the work flow for adult education are: group work and individual work.

\section{Areas of the Process of Adult Education and Adult Learning Styles}

Summarizing the European and the world's leading scientists experience, the following target groups of people for adult education can be formed:

- people who have not got compulsory education at the necessary age;

- people who have a necessity to improve their knowledge and skills;

- people who have lost their job;

- people whose amount of work and interests motivate them to go on with their education according to the interests;

- retired people.

According to the suggestions provided by Koke T. (Koķe T., 1999), these are the most important areas of the process of adult education correspondingly to people's interests: late or second chance education, professional education, acquirement of social roles, education directed towards welfare, education directed towards the need of self-implementation.

Late or second chance education provides an opportunity to compensate a lack of education which could not be received at the necessary age due to particular reasons. People can take it up when they are ready or when all the circumstances are favourable.

Professional education is offered for people who need to learn the basic skills for a successful incorporation into the labour market, and for those who need to improve their current qualification accordingly to the contemporary requirements of modern technologies in the context of a creative and innovative action.

In the acquirement of social roles people are offered to comprehend and adopt the roles which they have to realize in the family and social sphere.

Education directed towards the social welfare try to protect people from possible social harms that they can eventually face, the negative impact of ignorance and other reasons while being in a social environment.

Education directed towards the need of self-implementation is related to the development of one's critical thinking and motivating the implementation of social changes that helps to comprehend themselves and the world.

Gardner H. (1983) theory of multiple intelligences in which at least seven most characteristic abilities of people are revealed is very topical nowadays. It comprises linguistic, logical-mathematical, spatial, musical, bodily-kinaesthetic, intrapersonal and interpersonal abilities. Everyone has a different level of their development. While organizing the process of adult learning, it is important to take into account one's dominating abilities as well as to promote the activation of the less developed ones (see Table No.1). 
Proceedings of the International Scientifical Conference. Volume II: Social and Special pedagogy; Health and Sport; Overviews.

Table 1

\section{Adult Learning Styles Connected With Comprehensive Abilities}

(Gardner)

\begin{tabular}{|c|c|c|c|}
\hline Abilities & Likes & Is Good at & Way of Learning \\
\hline Linguistic & $\begin{array}{l}\text { Reading, writing, } \\
\text { telling }\end{array}$ & $\begin{array}{l}\text { Remembering words, } \\
\text { names }\end{array}$ & $\begin{array}{l}\text { Articulation, } \\
\text { listening, watching }\end{array}$ \\
\hline $\begin{array}{c}\text { Logical- } \\
\text { Mathematical }\end{array}$ & $\begin{array}{l}\text { Experimenting, } \\
\text { operating } \\
\text { numbers, with } \\
\text { questions, analyzing } \\
\text { examples }\end{array}$ & $\begin{array}{l}\text { Calculation, } \\
\text { reasoning }\end{array}$ & $\begin{array}{l}\text { Dividing into } \\
\text { categories, } \\
\text { classification, } \\
\text { abstraction }\end{array}$ \\
\hline Spatial & $\begin{array}{l}\text { Drawing, } \\
\text { constructing, } \\
\text { watching pictures, } \\
\text { films }\end{array}$ & $\begin{array}{l}\text { Imagining, intuition, } \\
\text { matching puzzles, } \\
\text { reading maps }\end{array}$ & $\begin{array}{l}\text { Imagining, dreaming, } \\
\text { working with colours }\end{array}$ \\
\hline Musical & $\begin{array}{l}\text { Singing, listening to } \\
\text { music, playing } \\
\text { musical instruments }\end{array}$ & $\begin{array}{l}\text { Detecting sounds, } \\
\text { remembering } \\
\text { melodies, } \\
\text { considering rhythm } \\
\text { and time }\end{array}$ & $\begin{array}{l}\text { Basing on rhythm, } \\
\text { melody }\end{array}$ \\
\hline Bodily-kir & $\begin{array}{l}\text { Touching, speaking, } \\
\text { using body language }\end{array}$ & Physical activities & $\begin{array}{l}\text { Touching, moving, } \\
\text { acquiring knowledge } \\
\text { by bodily feelings }\end{array}$ \\
\hline Intrape & $\begin{array}{l}\text { Making a number of } \\
\text { friends, inclusion in } \\
\text { the group }\end{array}$ & $\begin{array}{l}\text { Understanding each } \\
\text { other, managing } \\
\text { others, addressing } \\
\text { disagreements }\end{array}$ & $\begin{array}{l}\text { Sharing the } \\
\text { experience, } \\
\text { comparing, } \\
\text { operation }\end{array}$ \\
\hline Interpersonal & Being solitary & $\begin{array}{l}\text { Managing oneself, } \\
\text { concentrating } \\
\text { one's feelings }\end{array}$ & $\begin{array}{l}\text { Working } \\
\text { individually, needs } \\
\text { for a personal space }\end{array}$ \\
\hline
\end{tabular}

\section{Innovations as a Source of Increasing the Viability and Competitiveness of an Entrepreneurship}

Innovation is a process in which new scientific, technical, social, cultural or other ideas are implemented in the market along with other developments and technologies in a form of a marketable and competitive product or service.

Innovation support structures - institutions which support the commercialization of research results and the creation of new businessmen which are oriented towards technologies. Innovation supporting structures comprise science and technology parks, technological and innovation centres, business incubators and other similar institutions.

Innovative entrepreneurship comprises the following:

- it has started to produce at least one competitive product or to provide service during the past 3 years or it has used modern technologies for increasing the competitiveness of the existing products; 
- its new product is based on the knowledge, which has been created in the same entrepreneurship or as the result of co-operation with scientific research institutions (universities, research institutes), separate experts or other entrepreneurs in and beyond the territory of Latvia;

- it invests in the development of new products at least $0.5 \%$ of its annual turnover;

- during its action at least two of three following criteria are implemented: at least $25 \%$ of the annual turnover are obtained from the products which are not older than five years; income from products which are not older than five years constitute at least $10 \%$ of all the annual turnover; sales volume of new products or services increase annually by at least $5 \%$.

Scientist Baumane-Vitolina I. (Baumane-Vìtolina I., 2010) developed theory about business resources as innovation influencing factor. Sustainable community development relates to co-operation for solving economical, environmental and social issues in an integrated and innovative way. Horizontal co-operation, for instance, among cities, institutions of different spheres or business organizations of various spheres, allows combining the available resources in new ways and solving such problems together that sometimes go beyond their impact. Vertical cooperation, for example, among institutions of different countries, regions and local institutions, municipalities, businessmen and people provides an opportunity to make more effective decisions and find optimal solutions. For reacting to new situations in a flexible, fast and innovative manner, such institutional, academic environment of enterprise is necessary in which separate institutions can co-operate in an effective and innovative way.

\section{The Development of Innovative Business in the Context of Quality of the Organization}

An innovative businessman - it is a businessman who creates and develops innovative products or processes and distributes them into the market in a particular period of time. The most important mainsprings are: a creative individual and society that is able to evaluate and use its creative potential.

An innovative product - a product that promotes an establishment of a new market niche or which is more different from the products and services provided before.

The authors of the article offer a scheme of an innovative business (see Figure No.1). For distributing a new and innovative product, it is important to have a business idea followed by the research and realization of the idea comprising its implementation processes.

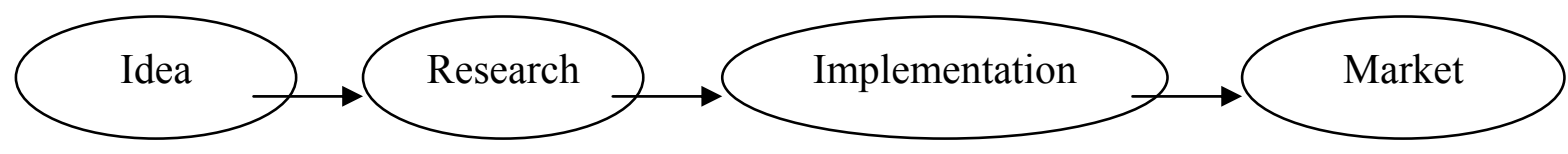

Figure 1. Stages of the innovative business 
The performance (efficiency, effectiveness) of organizations and institutions related to entrepreneurship can be characterized as the use of effective and expedient resources for reaching particular results. A scientist Sarnovics A. (Sarnovičs A., 2010) offers a model of the organization's operational effectiveness (see Figure No.2) and provides an opportunity to study the link among four measuring parameters of the organization's activities: investments (resources, expenses, and staff), activities and process (activities, measures, and processes), result of the action (provided service) and results of the policy (results, achievements, impact). This model proves the logic of a strategic plan and shows the links among actions which help to achieve good results. The first three parameters provide an answer to the question "whether things have been performed in a right way," but the fourth one helps to decide "whether the right things have been performed." Results of actions reflect measurable results of the actions of different institutions which contribute to the achievement of policy results, whereas policy results show the preferable (planned) positive changes in the society. The results of actions and policy are the main measurements of the implementation of policy goals and evaluation of the accomplishment of operational tasks. If there are any differences between the goals set by organization and the results that must be achieved, it means that it is necessary to verify if the goals are real, if the operational programme is based on the goal, if the necessary management and control is provided, if all the necessary resources for implementing the programme are allotted and if they are used in an expedient way. The operational effectiveness of the organization used in the scheme is based on educated and innovative staff, which performs a lifelong education.

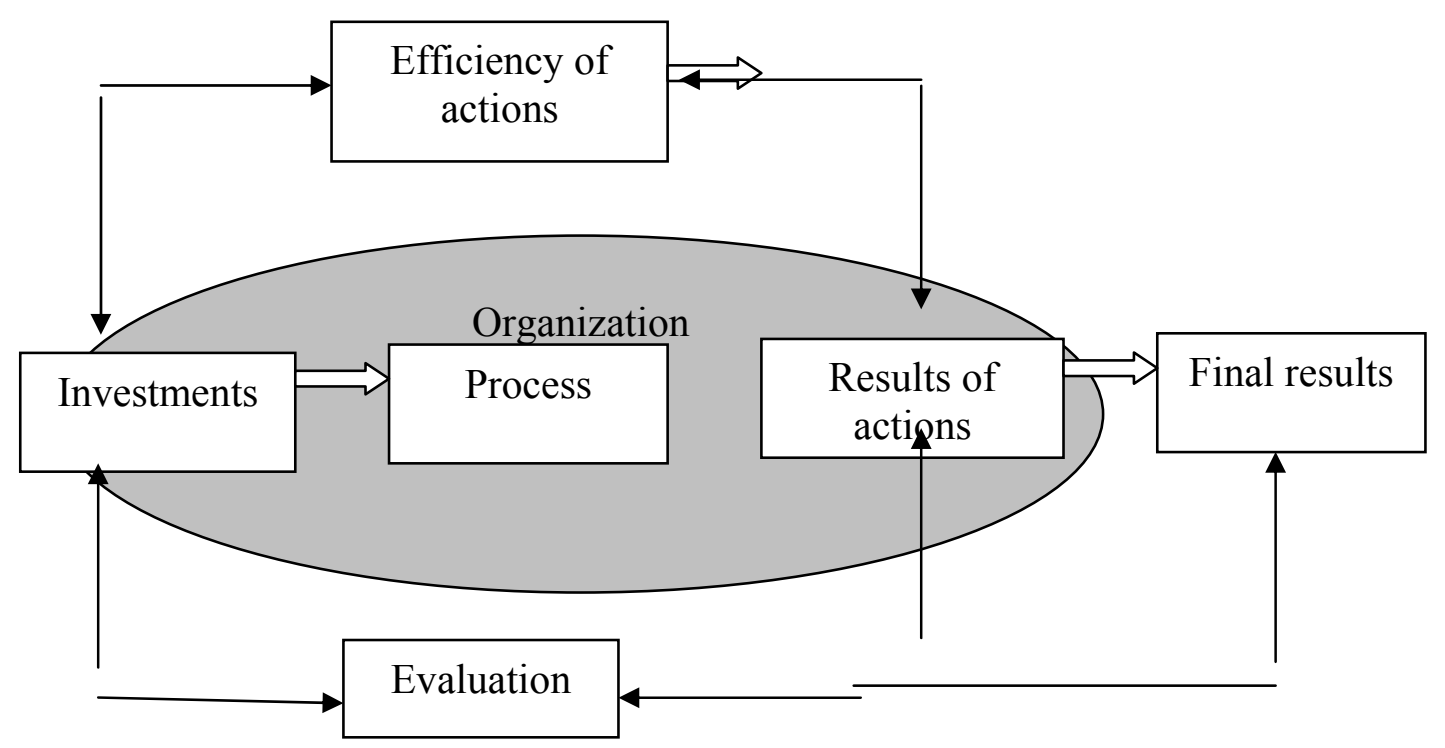

Figure 2. A Model of the Organization's Operational Effectiveness (Sarnovics) 
It is indicated in the Latvian strategy of a sustainable development until the year of 2030 that human capital is the most important resource in Latvia, whereas innovation is one of the most significant mainsprings of the development. Innovation results form the ability to create new ideas, notions, methods and forms of action or to link the existing ideas, concepts, methods and actions in a new way. Innovation as a strategic principle has to be comprehended in the broadest sense by relating it not only to science, but also to any sphere of the social or economic life. Any product or service created as a result of the innovative performance is the basis of the future of the global economy.

\section{Trends of Innovative Actions in Latvia and Europe}

The number of innovative enterprises in Latvia is small, constituting only $17 \%$ of all enterprises. Also the number of patents is scarce - only 6 patents of the European Patent Office per 1 million of people, whereas the average amount of patents in the EU countries is 120. Latvian export of high-tech constitutes $3.2 \%$, but in Europe $-18.4 \%$. There are an insufficient number of doctoral students in Latvia - only $0.13 \%$ of all students aged from 20 to 29 years (in Finland - 1.33\%). Even the increase of doctors is scarce (140 doctors in 2010). Such innovative specialities like natural sciences, mathematics, informatics has been chosen only by $14 \%$ of all the doctors. About 4500 people are employed in the area related to science. From all the working scientists there are about 2000 people with a doctor degree (including part-time work). New knowledge and its use in a rational and purposeful way is the most significant resource for reaching the quality of individual and social life characteristic to developed countries (Central Statistical Bureau of Latvia and Eurostat, European Commission).

Unfortunately both material and human resources which can be used by Latvian enterprises for an innovative development of actions are not sufficient. Therefore, it is important to involve highly qualified academic staff for developing new products and their co-operation with business environment. It is considered to be a decisive precondition of the development of innovative economics. Cooperation among universities, scientific institutions and enterprises shall be oriented towards the innovative capacity of enterprises, the increase of academic institutions' cognition of entrepreneurship and the integration of the society's intellectual potential and business qualification of businessmen, thus reaching synergistic effects and radically increasing research yields in the Latvian economy.

However, as it is shown in the analysis of this situation only few enterprises co-operate with researchers and the major part of them even does not know and cannot imagine the fact that researchers can take part in the creation of new products and their improvement. Some scientists are also not active enough in communication with enterprises, because some of them consider it to be a degradation of the science. Overcoming the large gap between the research and business environment is a very important task at the national level. Every activity performed for reaching this goal is of great importance: 
Proceedings of the International Scientifical Conference. Volume II: Social and Special pedagogy; Health and Sport; Overviews.

- development of the principles of innovative entrepreneurship and methodology along with the model of co-operation (legal, financial, institutional, etc.) among scientific research institutions and enterprises;

- a programme of applied research and innovative projects shall be implemented with a state defined topic and compulsory business co-financing for different projects; it would decrease business expenses of the development of new products and increase their successful distribution in the market;

- a special state programme for linking business co-financing and applied innovative projects supported by the EU structural funds would considerably increase the level of innovations in the entrepreneurship;

- Latvia is too small for creating competitiveness among research institutions in making new researches; therefore, it is essential to establish a unified Latvian science centre for preventing fragmentation of applied research, coordination and merging their capacity;

- creation of specialized technological centres (parks), business incubators (parks) and supporting activities of priority industries; the availability of different outsourcing to integrated innovative enterprises is of great importance, thus providing an opportunity to concentrate on their basic work.

Another important aspect is related to the necessity for some changes in the mentality of people living in Latvia. A typical insufficient level of the initiative is noticed here, due to the fact that only a few people are ready to take business risk and become an employer. It is obvious that traditional fear of the failure and bankruptcy are still at a high level, but innovative business is related to taking higher risks, because previous actions and/or the success of the previous product does not guarantee the success in the future. By adding a disbelief to our and state's perspectives in the future as well as a trend to accentuate our failures and showing the inner problems beyond the territory of our country (unfortunately, media is one of such sources) we do not create an impression of a strong and self-confident partner. It is a huge harm to our development, and it is also a reason of such low evaluation of our country in different ratings.

The management of knowledge at the national level, contributions to human resources, purposefully organized work of a lifelong education and adult education is evaluated as preconditions of the development of the country. It is noted in the Latvian Sustainable Development Strategy 2030 that innovative, eco-effective and competitive economy shall be based on the initiative and environment that supports entrepreneurship. The support for creating and commercializing new ideas, transfer of knowledge, research directed by the users, science at the global level, innovations and transition to the creation of products and services with a low level of carbon emissions and energy content, the use of renewable resources and development of new technologies, healthy food and commercialization of ecosystem services are only a part of all the ways of perspective economical development.

Europe 2020 strategy is based on three priorities: 
- smart growth - development based on the knowledge and innovations;

- sustainable growth - promoting more effective, more environmentally friendly and competitive economy in terms of resources;

- inclusive growth - ensuring such economy, which comprises higher level of employment and provides economic, social and territorial cohesion.

These priorities justify smart, sustainable and inclusive growth that is based on educated society and innovative entrepreneurship.

\section{Conclusions}

1. Qualitatively and purposefully organized adult education has a crucial role in the development of innovative entrepreneurship.

2. For distributing a new and innovative product having a business idea is of great importance followed by research, implementation of the idea and its adoption.

3. Innovation is a process in which new scientific, technical, social, cultural or other ideas are implemented in the market along with other developments and technologies in a form of a marketable and competitive product or service.

4. Innovation comprises all the community activities starting with education and including scientific research work, protection of the intellectual property, organization of production, and research of the market and distribution of products in the market interacting with the arrangement of entrepreneurship environment and establishing innovation support structures.

5. The quality indicators of human resources and innovative actions are the basis of the social and economical life in economically developed countries.

6. Innovative entrepreneurship is oriented towards the human ability to create and use knowledge in constantly changing circumstances and being responsible for their actions.

7. Adult takes part in his further education for obtaining things which are necessary for his self-implementation.

8. Adult education is affected by collaboration of the state, employer, employee and educational system.

9. Adult education is a part of educational system that provides an opportunity of a lifelong learning to people according to their needs and abilities as well as trends of the nature and community development, regardless of their previous education level.

10. Trainees involved in the process of adult education can be divided into the following groups: hardworking trainees, impulsive trainees, friendly trainees, negatively minded trainees, trainees loving to take risks and unconfident trainees.

11. While organizing the process of adult learning, it is important to take into account one's dominating abilities as well as to promote the activation of the less developed ones - linguistic, logical-mathematical, spatial, musical, bodilykinaesthetic, intrapersonal and interpersonal abilities.

12.Human resources are the main Latvian development resources, but innovation is one of the most significant mainsprings. 
Proceedings of the International Scientifical Conference. Volume II: Social and Special pedagogy; Health and Sport; Overviews.

13. Effectiveness of the organization is characterized by the following parameters: investments (resources, expenses, and staff), activities and process (activities, measures, and processes), result of the action (provided service) and results of the policy (results, achievements, impact).

14. The quality of community development is characterized by the following priorities - smart growth, sustainable growth and inclusive growth.

\section{Bibliography}

1. Baldiņš, A. (2005). Andragoǵija. Teorija. Prakse. Metodika. Rīga: RTU Izdevniecība.

2. Baumane-Vìtoliņa, I. (2010). Uzņēmumu resursi kā inovācijas ietekmējošais faktors. Rīga: Latvijas Universitāte.

3. Beļickis, I., Blūma, D., Koķe, T. u.c. (2000). Pedagogijas terminu skaidrojošā vārdnīca. Rīga: Zvaigzne ABC.

4. Darkenwald, G.G., Merriam, S.B. (1982). Adult Education: Foundations of Practice. New York.

5. Eiropas Komisija. (2000). Mūžizglìtības memorands. Brisele.

6. Eiropas Komisija. (2010). Eiropa 2020. Stratēgija gudrai, ilgtspējīgai un integrējošai izaugsmei. Brisele.

7. Gardner, H. (1983). Frames of Mind. New York: Basic Books.

8. Knowles, M.S. (1988). The Adult Learner. Texas: Gulf Publishing.

9. Koķe, T. (1999). Pieaugušo izglītības attīstība: raksturīgās iezīmes. Rīga: SIA Mācību apgāds NT.

10. Latvijas ilgtspējīgas attīstības stratēgija līdz 2030.gadam. (2010). Rīga: LR Saeima.

11. Latvijas nacionālais attīstības plāns 2007 - 2013. (2006). Rīga: LR Reǵionālās attīstības un pašvaldību lietu ministrija.

12. Latvijas pieaugušo izglītîbas apvienība. (1997). Pieaugušo izglìtības gadagrāmata. Rīga: LR Izglītības un Zinātnes ministrija.

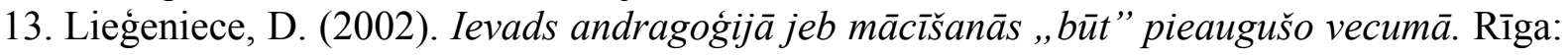
RaKa.

14. Lonstrupa, B. (1995). Mācīt pieaugušos - ar atklātību. Denmark: Forlaget KLIM, Horning Kreative Center.

15. Pelše, G., Ruperte, J. (2003). Uzn̄èmēja rokas grāmata. Rīga: SIA J.L.V.

16. Rurāne, M. (1998). Uzņēmējdarbības pamati. Rīga: Turības mācību centrs.

17. Sarnovičs, A. (2010). Cilvēkresursu mērķtiecīga attīstība valsts pārvaldē un tās pilnveidošanas virzieni. Rīga: Latvijas Universitāte

18. Slavinska, I. (2003). Uzņēmējdarbības plānošana un kontrole. Rīga: Biznesa augstskola Turība.

19. Stašāne, J. (2007). Pieaugušo izglītības pārvaldība kā mūžizglītības veicināšanas nosacījums. Rīga: Latvijas Universitāte.

20. Svence, G. (2003). Pieaugušo psihologija. Personības brieduma perioda attīstības akcenti un profesionālà motivācija. Rīga: RaKa.

21. Šibajevs, V. (2002). Neformālā izglītība interešu centros. Rīga: RaKa.

22. Timmons, Jeffry, A. (1994). New venture creation: entrepreneurship for the 21st century. New York, USA: WM. C. Brown Communications, Ins.

23. UNESCO. (2000). Nākotnes izglītības meti UNESCO Starptautiskās komisijas „Izglītība divdesmit pirmajam gadsimtam" zinojumā. Rīga: UNESCO.

24. Zinātne, pētniecība un inovācija Latvijas izaugsmei. (2007). Rīga: SIA Apgāds Zinātne.

25. http://polsis.mk.gov.lv/view.do?id=2169 
SOCIETY, INTEGRATION, EDUCATION. May $25^{\text {th }}-26^{\text {th }}, 2012$.

26. http://www.likumi.lv/doc.php?id=50759

27. http://www.csb.gov.lv/dati/dati-245.html

28. http://epp.eurostat.ec.europa.eu/portal/page/portal/statistics/search_database

\begin{tabular}{|cl|}
\hline Daina Silakalne - Arāja & University of Latvia \\
& Raina bulv.19, Riga, LV-1586, Latvia \\
& E-mail: danha@inbox.lv; Phone: +371 28865022 \\
\hline Raimonds Arājs & Rezekne Higher Education Institution \\
& Personality Socialization Research Institute \\
& Atbrivosanas aleja 115, Rezekne, LV-4601, Latvia \\
& E-mail: arajsraimonds@inbox.lv; Phone: +371 29529884 \\
\hline
\end{tabular}

